International Journal of Computer Science \& Information Technology (IJCSIT), Vol 3, No 1, Feb 2011

\title{
ELECTRE METHODS IN SOLVING GROUP DECISION SUPPORT SYSTEM BIOINFORMATICS ON GENE MUTATION DETECTION SIMULATION
}

\author{
Ermatita *1, Sri Hartati*2, Retantyo Wardoyo*2, Agus Harjoko*2 \\ *1Department of Information System , Computer Science Faculty of Sriwijaya \\ University Indonesia \\ (Doctoral Program Student Computer Science Gadjah Mada University ) \\ Jl. Palembang-Prabumulih, Ogan Ilir, INDONESIA \\ 1ermatitaz@yahoo.com \\ *2 Departement of Computer Science and Electronics Mathematics and Natural \\ Sciences Faculty Gadjah Mada University, Indonesia
}

\begin{abstract}
Analysis of genes expression can be done with the investigation of a particular microarray data for the description of a gen. This is done to identify what genes that were active in the human body. Detection of gene mutation is an activity that can provide contribution in the medical field. Detection of mutated gene is needed to avoid the diseases caused by them such as cancer. The detection of gene mutations can be performed by utilizing computer-based system. Group Decision Support System (GDSS) is a computer-based system that can be utilized in detecting human gene mutations that cause disease. The ELECTRE method, which is a Multi-Attribute Decision Making, is a method in modeling multi-criteria GDSS. In this paper we propose implementation of model for multi-criteria GDSS in which the simulation data is the mutated genes that can cause cancer
\end{abstract}

\section{KEYWORDS}

Bioinformatics, Group Decision Support System, ELECTRE, gene mutation

\section{INTRODUCTION}

Bioinformatics is application of sciences the computational technique to manage and analyze biological information. One of the activities in bioinformatics is investigations of human genes and microarray data. A Group Decision Support System (GDSS) is a computer-based systems to support a collection of groups who have a common task or goal. This system typically provides an interface for users who are the member of the group. The GDSS can accelerate decision-making process or improve the quality of the resulting decisions, or both. This can be done with the support for the exchange of ideas, opinions, and choices in the group on the system. The Group Decision Support System can be applied to the field of information technology which is able to assist in providing decision regarding mutated genes that may or may not cause cancer.

Some alternative methods for the determination of group decision making have been improved by researchers. This method was developed to determine the best alternative from several alternatives based on criterion in making decisions. One of the method in decision making 
International Journal of Computer Science \& Information Technology (IJCSIT), Vol 3, No 1, Feb 2011

group is Multiple Criteria Decision Making (MCDM). The MCDM is divided into two models: Multi-Attribute Decision Making (MADM) and Multi-Objective Decision Making (MODM). The decision to justify whether the genes affected by genes causing cancer can be done by conducting ranking MCDM ELECTRE method. For that purpose, we need a model in decisionmaking process to detect the gene mutations that can cause cancer. In this paper, we propose implementation of GDSS Model by using the ELECTRE method to detect gene mutations simulation in mathlab aplication. This model is made by using a simulation of the some defined criteria.

\section{BACKGROUND THEORIES}

\subsection{GROUP DECISION SUPPORT SYSTEM (GDSS)}

GROUP DECISION SUPPORT SYSTEM (GDSS) is an interactive computer based system that facilitates solution of some unstructured problems by a few (sets) of decision makers who work together as a group. GDSS can be applied to different groups of decision situations (group), which includes a review panel, task force executive meeting / board, remote workers, and so forth. The basic activities that occurred in any group and who require support on a computer are:

- Calling information, involving the selection of data values from an existing database or calling simple information.

- Information sharing, meaning the viewer displays the data on the screen to be viewed by groups.

- Use of information, including application software technology, procedure, and group problem solving techniques to the data. [8]

\subsection{MULTI- CRITERIA DECISION MAKING}

Multi-criteria decision making (MCDM) is the decision-making technique by considering some alternatives options. The Decision making MCDM technique is done by the selection or formulation of attributes, objectives, and different goals, in which these attributes, objective or purpose are considered as the criterion. The criteria are measures, rules or standards that guide the decision making process. The criteria are built from the basic human needs and the values of interest. There are two kinds of categories of Multi-criteria decision making (MCDM),[3], namely:

\section{Multiple Objective Decision Making (MODM)}

\section{Multiple Attribute Decision Making (MADM)}

The Multiple Objective Decision Making (MODM) comes to the design, where mathematical optimization techniques are used. This types of MCDM is useful for a very large number of alternatives (up to infinity) and to answer the question about what and how much. In addition, the MODM is used to solve problems in continuous space, such as problems in mathematical programming. The MODM is design by using the best alternative. [3]

The Multiple Attribute Decision Making (MADM), comes to elections, in which mathematical analysis is not needed. This type of MCDM can be used for the election in which there is only a small number of alternative courses. The MADM is used to solve problems in discrete spaces, 
International Journal of Computer Science \& Information Technology (IJCSIT), Vol 3, No 1, Feb 2011

typically used to solve problems in the assessment and selection of limited number of alternatives.

The MADM approaches are done through two stages, namely:

1. Perform aggregation of the decisions that responds to the decisions corresponding to all destinations on each alternative

2. Perform alternatives ranking based on the aggregation of the decision makers. [3]

According[4]: MADM is evaluated against the alternative $\mathrm{m} \mathrm{Ai}(\mathrm{i}=1,2, \ldots ., \mathrm{m})$ against a set of attributes or criteria $\mathrm{Cj}(\mathrm{j}=1,2, \ldots, \mathrm{n})$ where each attribute are not mutually dependent with each other. Decision matrix of each alternative on each attribute, $\mathrm{X}$ is given as:

$$
X=\left[\begin{array}{cccc}
x_{11} & x_{12} & \cdots & x_{1 n} \\
x_{21} & x_{22} & \cdots & x_{2 n} \\
\vdots & \vdots & \cdots & \vdots \\
x_{m 1} & x_{m 2} & \cdots & x_{m n}
\end{array}\right]
$$

Where $\mathrm{x}_{\mathrm{ij}}$ is an alternative performance rating in relation to the $\mathrm{j}$-th attribute. Weight value indicates the relative importance of each attribute, given as, $\mathrm{W}$ :

$\mathrm{W}=\left\{\mathrm{w}_{1}, \mathrm{w}_{2}, \mathrm{w}_{3}, \ldots, \mathrm{w}_{\mathrm{n}}\right\}$

Performance rating $(\mathrm{X})$ and weight value $(\mathrm{W})$ represent the core values corresponding to the absolute preference of the decision makers. The MADM problems is finalized with an alternative process to get the best ranking obtained based on the overall value of granted preferences (Yeh, 2002) in [4].[4]

\subsection{ELECTRE}

The ELECTRE (Elimination Et Choix Traduisant He realite) is based on the concept of ranking by paired comparisons between alternatives on the appropriate criteria. An alternative is said to dominate the other alternatives if one or more criteria are met (compared with the criterion of other alternatives) and it is equal to the remaining criteria. Ranking relations are between two alternatives Ak from the A1 (Roy, 1973) in [4].

The researches on the ELECTRE method has been widely applied, for example:

[9] conducted a study: The ELECTRE method based on interval numbers and its application to the selection of leather manufacture alternatives. In this study, it is studied how to make use of traditional methods for certain circumstances to solve the MADM with interval numbers. The paper proposes an enhanced ELECTRE method based on the number of intervals. This is performed by considering the specificity of interval numbers, using the possibility degree for ranking alternatives, founded the discordance dominance matrix and aggregate dominance matrix, then eliminating inferior alternatives. This method can be used to MADM, where the values of attributes in the form of interval numbers, and solve the difficulties in ranking a number of intervals in the traditional method. The selection of leather-making problem solving with this method, and illustrated its application in real life.

[9] In this study, using the possibility degree of interval to propose an alternative ranking and the ELECTRE method based on interval numbers, and it gives step to perform using this 
International Journal of Computer Science \& Information Technology (IJCSIT), Vol 3, No 1, Feb 2011

method. This method can be used to solve the problem of multiple solutions attribute decision in which the attribute values are numbers intervals. [9]

[2] in his research on MADM methods associated with the decision maker's point of view about the Importance degree of responses. The results given is assumed that the response-means clustering is more important than the standard deviation. Another advantage of this method is it considers the standard deviations that contribute to the strength of experimental design, because it only uses one appropriate response regression function, so that this method reduces the statistical error. Because this method attempts to obtain a value of several responses, then it can be grouped in the desirability function approach.

[5] in his research develop methods that VIKOR compared with ELECTRE II method in the method of ranking. Opricovic get the result that the similarity of ELECTRE and VIKOR development based on the equality principle as:

(A) Consider the global certainty measure (concordance and group utility).

(B) opsisi of other criteria-the-minority'"'is not strong (nondiscordance).

Analysis and ELECTRE VIKOR comparison shows that with the assumptions, conditions and decisions by Rj"discordance"in VIKOR have in common with the basic MCDM (minimum individual regret).

[7] in his research develop new ELECTRE Method with Interval Data in Multiple Attribute Decision Making Problem This study aim is to provide new and unique method for ranking alternatives with interval data in multi-attribute decision making. The use of interval data is considered better than to use the interval data for the deterministic problem and the exact data (eg, time, distance, temperature) or they cannot easily be expressed as deterministic and specific numbers. in this study, they developed a method for decision making solution of problems (especially, when it is not possible to present the data so that the use of fuzzy fuzzy decision making. [1]

[7] conducted an applied research Analysis by an outranking multi-attribute decision-making technique, called Elimination et choix traduisant He realite method. This approach is applied to an illustrative example where Analytical hierarchy process method applied to calculate the global weights of the attributes of the couple through the comparison matrix. This study shows the proposed AHP-ELECTRE algorithm; outranking relations between the alternatives and in this way, non-dominated sets of land-use alternatives other alternatives can be identified. In this approach, the worst alternative for the examples given can be recognized as well. Results obtained by ELECTRE outranking is better than the TOPSIS ranking. This approach is beneficial especially when the number of alternatives more. This means that, further research is still needed to facilitate decision making MADM tool more appropriate to apply in the field of MLSA.

\subsection{ELECTRE METHOD FOR GENE MUTATIONS DETECTION SIMULATION}

Research that has been done is the development or testing of a particular method or technique in the field bioinformatics. This is intended to produce an analysis and prediction of gen in the micrroarray data and can provide stimulus for the best match and the conditions and circumstances of a particular man.

This paper proposes a modeling of MADM with ELECTRE method to detect gene mutations simulation in humans who suffer cancer. The mutations that might occur is that there is 
International Journal of Computer Science \& Information Technology (IJCSIT), Vol 3, No 1, Feb 2011

activation of the Rb gene c-myc gene or inactivation of p53 gene. In order to detect whether a person is identified to have cancer cells or not. The data were collected from the study of gene mutations [6]

Table.1 Expression of protein $\mathrm{p} 53, \mathrm{Rb}$ and c-myc

\begin{tabular}{|c|c|c|c|}
\hline No. sampel & p53 & $R b$ & myc- \\
\hline 1. & $30^{*}$ & 40 & 40 \\
\hline 2 & $30^{*}$ & 40 & 50 \\
\hline 3. & $30^{\star}$ & $30=$ & 60 \\
\hline 4. & 40 & $30=$ & 70 \\
\hline 5 & 50 & 50 & 40 \\
\hline 6. & 40 & 40 & 50 \\
\hline 7. & 50 & 40 & 70 \\
\hline B. & 40 & $30=$ & 60 \\
\hline 9 & $30^{*}$ & $20=$ & 40 \\
\hline 10. & 50 & 50 & $30 *$ \\
\hline 11. & 40 & $20=$ & 50 \\
\hline 12. & 40 & $30=$ & 50 \\
\hline 13 & 40 & $20=$ & $30^{\circ}$ \\
\hline 14. & 40 & 50 & 60 \\
\hline 15. & 50 & 40 & 70 \\
\hline 16 & 40 & $10^{=}$ & $30^{\circ}$ \\
\hline 17 & 40 & 60 & 70 \\
\hline 18. & 40 & 40 & 60 \\
\hline 19. & $30^{*}$ & $30=$ & 50 \\
\hline Rata-rata & 40 & 30,8 & 50,1 \\
\hline
\end{tabular}

Source (Prayitno,A. 2005)

In this simulation, it can be applied to the three alternatives in the set to the identification of cancer cells in the human gene, namely:

$\mathrm{A} 1=$ Inactivasi p53

$\mathrm{A} 2=$ activation $\mathrm{Rb}$

A3 = c-myc activation

Based on the gene expression in reference [6], there are three which reference in making decisions to detect a person experiencing the gene mutated, namely:

$\mathrm{C} 1=\mathrm{p} 53$ protein expression (in $\%)$

$\mathrm{C} 2=\mathrm{Rb}$ expression $(\mathrm{in} \%)$

$\mathrm{C} 3=\mathrm{c}-\mathrm{myc}$ expression $(\mathrm{in} \%)$

The suitability rating alternatives on each criterion will be the value of the numbers one to five, namely:

$1=$ very bad

$2=$ bad

$3=$ enough

$4=$ Good

$5=$ Very good 
International Journal of Computer Science \& Information Technology (IJCSIT), Vol 3, No 1, Feb 2011

Level of importance of each criterion in value by one to five, namely:

$1=$ very low

$2=$ Low

$3=$ enough

$4=$ High

$5=$ very high

From the above criteria, a match rating is made for each alternative on each criterion. The rating a match is made by simulation, that in determining the gene is mutated or not that actually fit all the criteria and rating is obtained from the opinions of experts. The simulated suitability rating of each criteria is indicated by the following table [10]:

Table.2 Suitability of each alternative on each criterion

\begin{tabular}{|c|c|c|c|}
\hline \multirow{2}{*}{ Alternatif } & \multicolumn{3}{|c|}{ Kriteria } \\
\cline { 2 - 4 } & $\mathrm{C} 1$ & $\mathrm{C} 2$ & $\mathrm{C} 3$ \\
\hline $\mathrm{A} 1$ & 4 & 4 & 5 \\
\hline $\mathrm{A} 2$ & 4 & 5 & 4 \\
\hline $\mathrm{A} 3$ & 4 & 3 & 5 \\
\hline
\end{tabular}

The calculation is done with the completion method Elimination Et Choix Traduisant He realite (ELECTRE), which is based on the concept of ranking by paired comparisons between alternatives on the appropriate criteria. An alternative is said to dominate the other alternatives if one or more criteria are met (compared to the criteria of other alternatives) and it is equal to the remaining criteria. The ranking relationship between the two alternatives $A_{k}$ and $A_{1}$ are denoted as $A_{k}{ }^{\circledR} A_{1}$ if alternative-k no-one dominates the alternative to the quantitative, thus better decision makers to take risks $A_{k}$ than $A_{1}$ (roy, 1973) in [4].

Decision matrix of the simulation above obtained as follows:

$\left[\begin{array}{lll}4 & 4 & 5 \\ 4 & 5 & 4 \\ 4 & 3 & 5\end{array}\right]$

Pairwise comparison of each alternative in each criteria is expressed by values (Xij). This value must be normalized to a scale comparable to $\left(\mathrm{r}_{\mathrm{ij}}\right)$. This value is calculated with the formula as below:

$$
\begin{aligned}
& r_{i j}=\frac{X_{i j}}{\sqrt{\sum_{i=1}^{m} X_{i j}^{2}}} \text { dengan } \mathrm{i}=1,2, \ldots . . \mathrm{m}, \mathrm{j}=1,2 \ldots \ldots \mathrm{n} \\
& \left|\mathrm{x}_{1}\right|=\sqrt{ } 4^{2}+4^{2}+4^{2} \\
& \left|\mathrm{x}_{3}\right|=\sqrt{ } 5^{2}+4^{2}+5^{2}
\end{aligned}
$$

From the results of calculations using the above formula in math lab : 
International Journal of Computer Science \& Information Technology (IJCSIT), Vol 3, No 1, Feb 2011

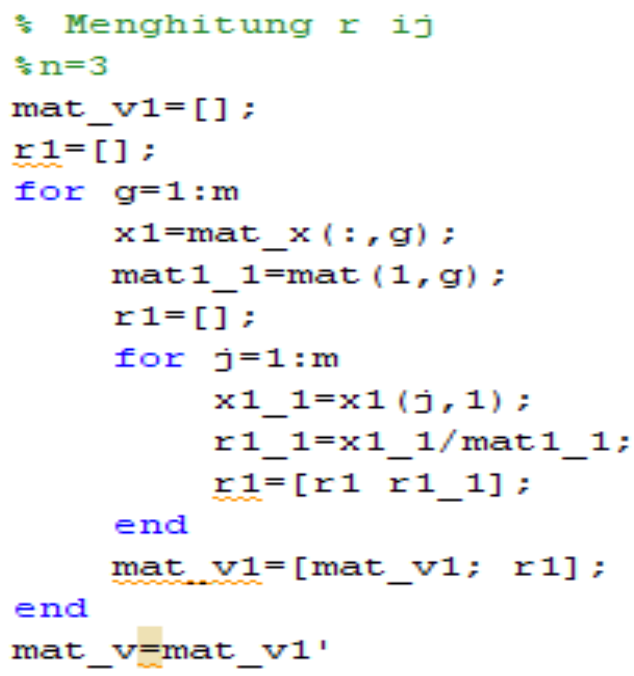

The result of calculation obtained as the matrix below:

$\left[\begin{array}{lll}0,57735 & 0,565685 & 0,615457 \\ 0,57735 & 0,707107 & 0,492400 \\ 0,57735 & 0,424264 & 0,615457\end{array}\right]$

Furthermore, the $\mathrm{V}$ matrix is calculated based on the equation:

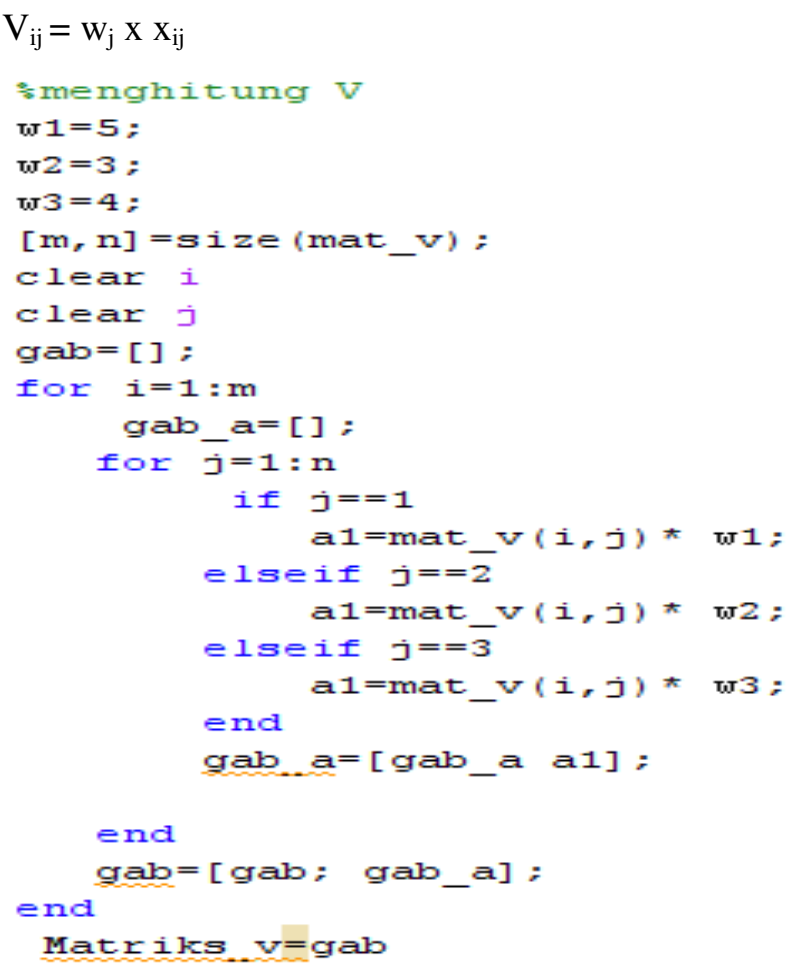

From the above calculation results obtained by matrix V: 
International Journal of Computer Science \& Information Technology (IJCSIT), Vol 3, No 1, Feb 2011

$\left[\begin{array}{lll}2,886751 & 1,697056 & 2,46183 \\ 2,886751 & 2,12132 & 1,96950 \\ 2,886751 & 1,27280 & 2,46183\end{array}\right]$

Calculated for the Association of concordance index $\left(\mathrm{C}_{\mathrm{kl}}\right)$ that shows the sum of weights of criteria, according to the formula;

$\mathrm{C}_{\mathrm{kl}}=\left\{\mathrm{j} \mid \mathrm{v}_{\mathrm{kj}} \geq \mathrm{v}_{\mathrm{ij}}\right\}$ for $\mathrm{j}=1,2, \ldots, \mathrm{n}$

The results obtained with this calculation is as follows:

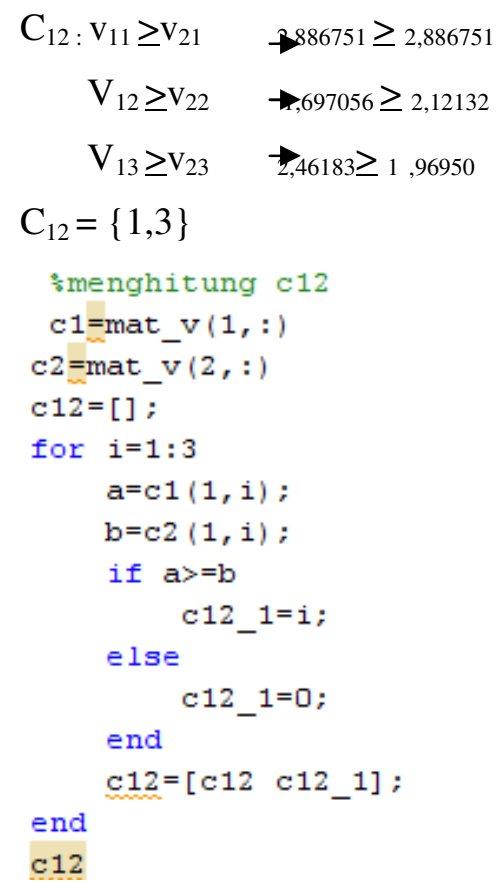

The same calculation for each $\mathrm{C}_{\mathrm{kl}}$ then obtained value of $\mathrm{C}$ as follows:

$\mathrm{C}_{12}=\{1,3\}$

$\mathrm{C}_{13}=\{1,2,3\}$

$\mathrm{C}_{21}=\{1,2\}$

$\mathrm{C}_{23}=\{1,2\}$

$\mathrm{C}_{31}=\{1,3\}$

$\mathrm{C}_{32}=\{1,3\}$

Calculating the value set for the matrix discordonce discordonce associated with the attribute is the following:

$d_{k l}=\left\{j \mid v_{k j}<v_{i j}\right\}$ untuk $j=1,2, \ldots, n$

$\mathrm{d}_{12}=\mathrm{v}_{11}<\mathrm{v}_{21} \quad \rightarrow_{2,886751}<2,886751$ 
International Journal of Computer Science \& Information Technology (IJCSIT), Vol 3, No 1, Feb 2011

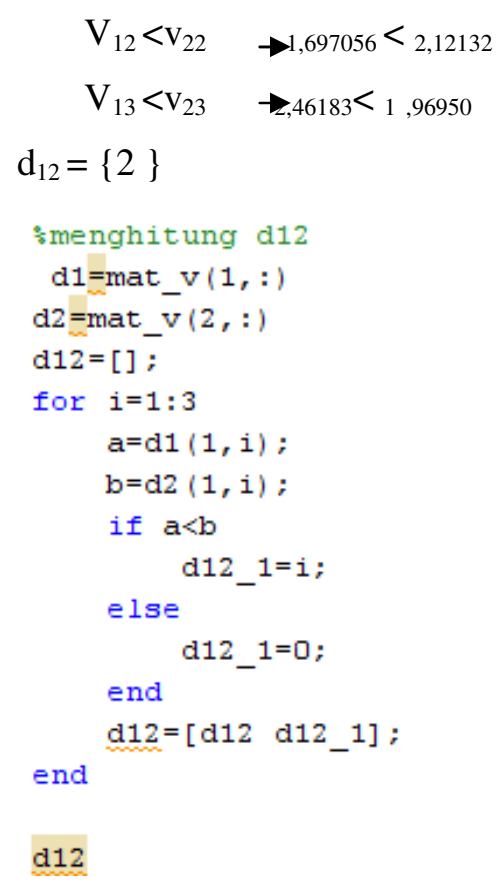

With a similar calculation for each element of the set obtained value D:

$\mathrm{d}_{12}=\{2\}$

$\mathrm{d}_{13}=\{\}$

$\mathrm{d}_{21}=\{3\}$

$\mathrm{d}_{23}=\{3\}$

$\mathrm{d}_{31}=\{2\}$

$\mathrm{d}_{32}=\{2\}$

$\mathrm{c}_{\mathrm{kl}}$ concordance matrix elements calculated using the formula :

$C_{k l}=\sum_{j \in c_{k l}} w_{j}$

Concordance matrix : $\mathrm{C}=\left[\begin{array}{ccc}- & 9 & 12 \\ 8 & - & 8 \\ 9 & 9 & -\end{array}\right]$

$\mathrm{d}_{\mathrm{kl}}$ discordance matrix elements calculated using the formula:

$d_{k l}=\frac{\max \left\{v_{k j}-v_{i j}\right\}_{j \in d_{k l}}}{\max \left\{\left|v_{k j}-v_{i j}\right|\right\}_{j \in v_{j}}}$

Matriks discordance: 
International Journal of Computer Science \& Information Technology (IJCSIT), Vol 3, No 1, Feb 2011

$$
\begin{array}{r}
\mathrm{D}=\left[\begin{array}{ccc}
- & 0,8 & 1 \\
0,2 & - & 1 \\
1 & 0,8 & -
\end{array}\right] \\
\underline{c}=\frac{\sum_{k=1}^{m} \sum_{l=1}^{m} c_{k l}}{m(m-1)}
\end{array}
$$$$
\underline{\mathrm{c}}=\frac{9+12+8+8+9+9}{3(3-1)}=\frac{55}{6}=9,16
$$

$\mathrm{d}$ is calculated using the formula:

$$
\underline{d}=\frac{\sum_{k=1}^{m} \sum_{l=1}^{m} d_{k l}}{m(m-1)}
$$

$\underline{\mathrm{d}}=0,8$

Concordance matrix calculated based on the dominant [10]

$$
\begin{gathered}
f_{k l}=\left\{\begin{array}{lll}
1, & j i k a & c_{k l} \geq \underline{c} \\
0, & j i k a & c_{k l}<\underline{c}
\end{array}\right. \\
\mathrm{F}=\left[\begin{array}{ccc}
- & 0 & 1 \\
0 & - & 0 \\
0 & 0 & -
\end{array}\right]
\end{gathered}
$$

elements of the matrix $\mathrm{F}$ is determined as the dominant discordance:

$$
\begin{aligned}
& g_{k l}=\left\{\begin{array}{lll}
1, & j i k a & d_{k l} \geq \underline{d} \\
0, & j i k a & d_{k l}<\underline{d}
\end{array}\right. \\
& \mathrm{G}=\left[\begin{array}{ccc}
- & 1 & 1 \\
0 & - & 1 \\
1 & 1 & -
\end{array}\right]
\end{aligned}
$$

Aggregation of the dominant matrix (E) showing a partial preference order of alternatives, obtained with the formula in mathlab:

$$
e_{k l}=f_{k l} \cdot g_{k l}
$$


International Journal of Computer Science \& Information Technology (IJCSIT), Vol 3, No 1, Feb 2011

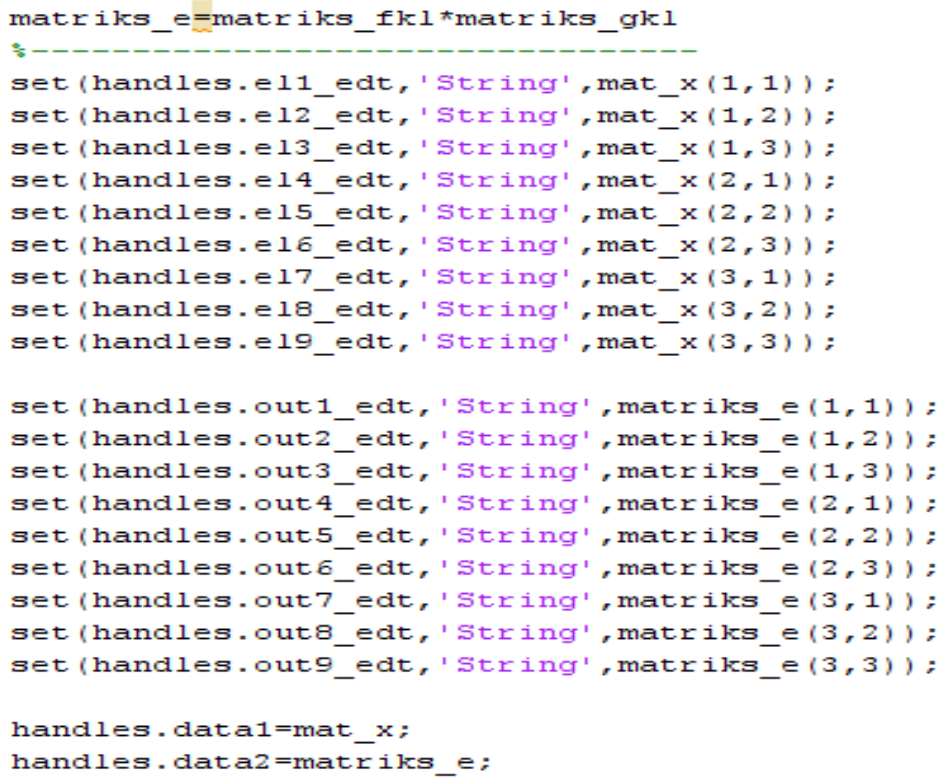

Result of the calculation is matriks above :

$$
\begin{aligned}
\mathrm{e}_{\mathrm{kl} l}=\mathrm{FxG} & =\left[\begin{array}{ccc}
- & 0 & 1 \\
0 & - & 0 \\
0 & 0 & -
\end{array}\right]\left[\begin{array}{ccc}
- & 1 & 1 \\
0 & - & 1 \\
1 & 1 & -
\end{array}\right] \\
& =\left[\begin{array}{ccc}
- & 1 & 0 \\
0 & - & 0 \\
0 & 0 & -
\end{array}\right]
\end{aligned}
$$

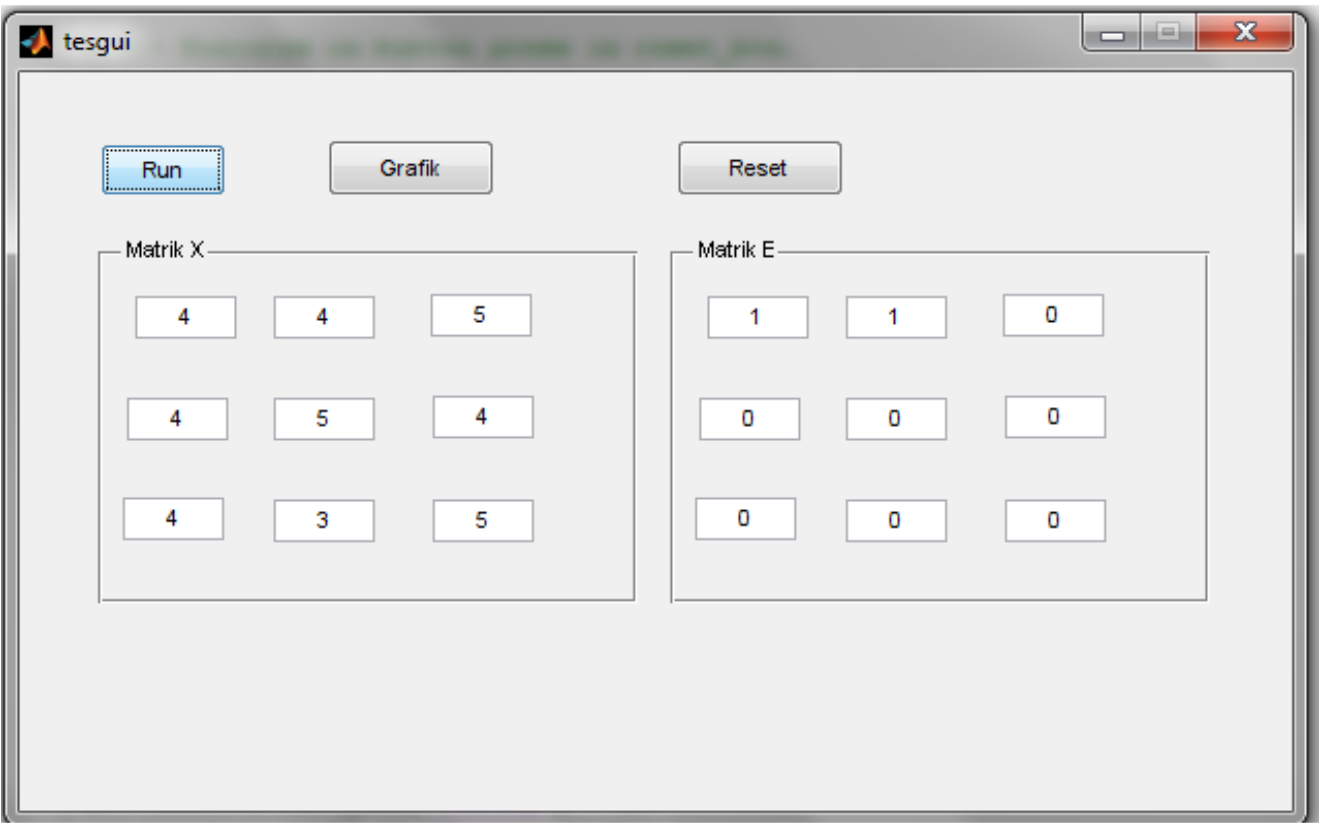

Fig.1 entry of criterion 


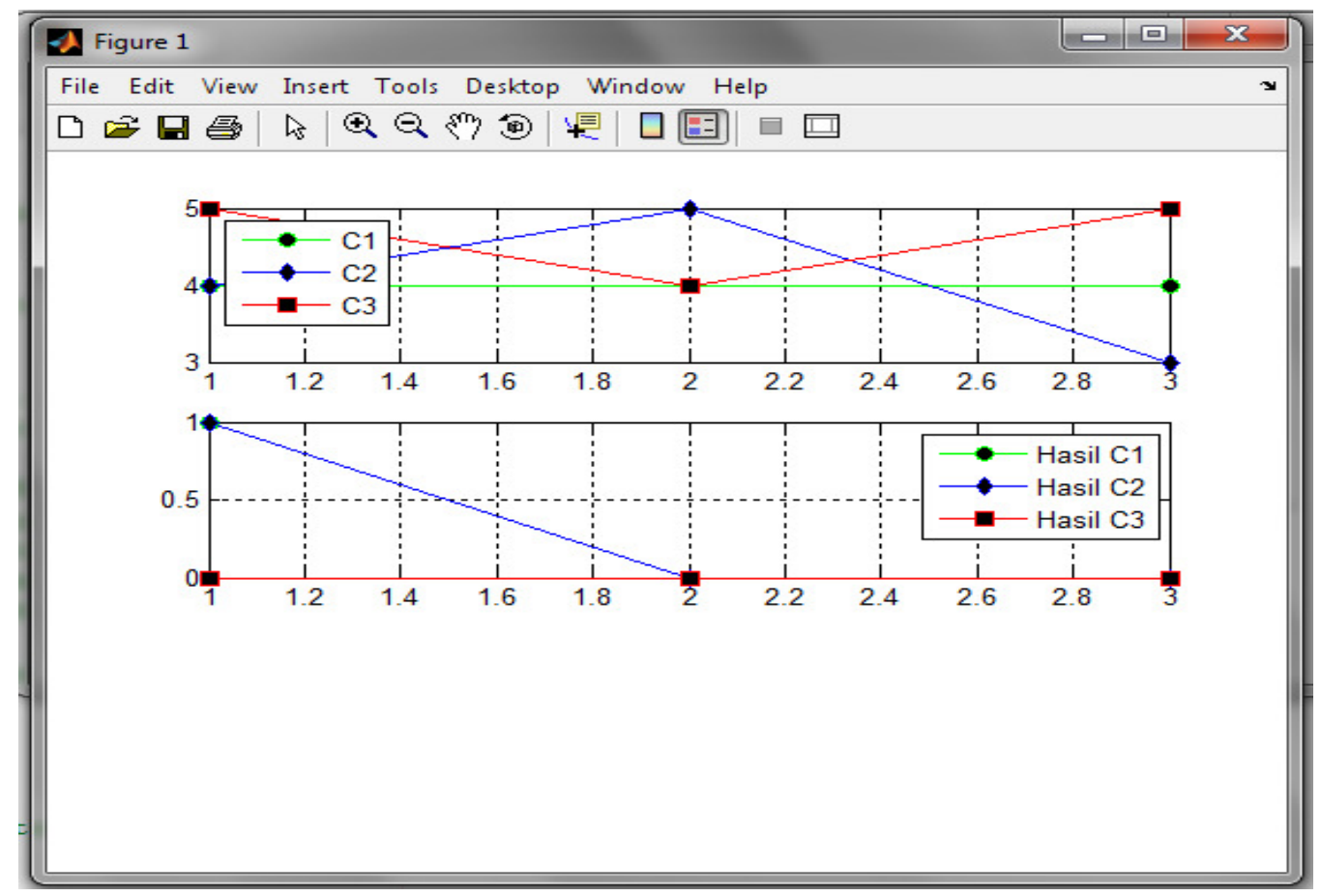

Fig.2 Graphic of result the calculation of model

From the above graphic is $A_{2}$ dominate $A_{1}, A_{2}$ also dominate $A_{3}$. In this simulation, which determined the criteria in Group Decision Support System in simulated from existing data. To simulate the model with the ELECTRE method is $A_{2}$ dominated $A_{1}$ and $A_{2}$ dominate $A_{3}$. This means that in this simulation of the criteria for determining the simulation showed that the activation of $\mathrm{Rb}$ more likely to cause cancer.

\section{Conclusions}

analysis of genes expression and micrroarray data done in order to meet the needs of their data to the gene expression and micrroarray data. For this activities need the methods for solution. The methods in Group Decision Support System such as ELECTRE can assist to analyze of gene. Decision group can assist in decisions made by a group of people. There are some group decision making methods have been developed, and ELECTRE method is one of the method in group decision making that can assist in the decision making process to determine whether a mutated gene can cause cancer or not, based on existing criteria in the gene mutation. This paper proposes the criteria in a for simulation implementation of modeling using ELECTRE method in mathlab. The results from the decisions is based on the determination of criteria for modeling. The determination of criteria for determining whether a mutated gene can cause cancer or do not has to refer to experts in their fields. This paper demonstrates the implementation of modeling to perform the calculation so that the decision can be modelled by using these calculations. This made the modelling flexible in accordance with the criteria established by the experts for decision making, so that the mutated gene for the determination of a person or not the criteria derived from expert opinion in the medical field. This modeling can be used for real life criteria, based on criteria established by the experts. 
International Journal of Computer Science \& Information Technology (IJCSIT), Vol 3, No 1, Feb 2011

\section{REFERENCES}

[1] Amiri, (2008) "Developing a New ELECTRE Method with Interval Data in Multiple Attribute Decision Making Problems".

[2] Bashiri, (2009) “An Extension of Multi-Response Optimization In MADM view”, Journal of applied Sciences 9(9); page 1695-1702, 2009

[3] R. Fitriadi, "Pendekatan Compromise Programming dengan memperhitungkan Faktor lingkungan (Studi Kasus Industri Otomotif PT"XX" Jawa Tengah)", Jurnal Ilmiah Teknik Industri Vol. 5 No. 2 Des 2006, hal 72 - 81, 2006

[4] S. Kusumadewi, S. Hartati, A. Harjoko, dan R. Wardoyo, (2006) "Fuzzy Multi-Attribute Decision Making (FUZZY MADM)”, Yogyakarta: Penerbit Graha Ilmu.

[5] S. Opricovic, G.H. Tzeng, (2005) "Extended VIKOR method in comparison with outranking methods", European Journal of Operational Research 178 (2007) 514-529, 2007

a. Prayitno, et All, "The expression of $p 53, R b$, and $c$-myc protein in cervical cancer by immunohistochemistry stain", Biodiversitas ISSN: 1412-033X Volume 6, Nomor 3 Juli 2005 Halaman: 157-159.

[6] Soltanmohammadi, (2008) "Achieving to some outranking relationships between post mining land uses through mined land suitability analysis", Int. J. Environ. Sci. Tech., 5 (4), 535-546, Autumn 2008 ISSN: 1735-1472@ Irsen, Ceers, IAU.

[7] E. Turban, (2005) "Dicision Support and Expert Systems: Management Support Systems", Fourth Edition, Prentice-Hall,Inc., United State.

[8] Q. Zhang and J. Ma, (2004) "Determining Weights of Criteria Based on Multiple Preference Formats", online pada http://www.is.cityu.edu.hk/Research/WorkingPapers/paper/0102.pdf 12 Oktober 2004, 2004

[9] Ermatita, et All, (2010) "MADM Methods in Solving Group Decission support sytem on Gene Mutation Detection simulation", Proceedings The second International Conference on DfmA 2010, ISBN:978-602-9747-9-0-4, August 2010, UGM, Yogyakarta

\section{AUTHOR BIOGRAPHY}

ERMATITA, WAS BORN IN LAHAT, SOUTH SUMATRA INDONESIA. LECTURER ON SRIWIJAYA UNIVERSITY, PALEMBANG, INDONESIA

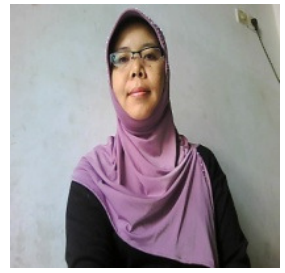

